\title{
ECONOMIC ANALYSIS OF SUSTAINABLE MANAGEMENT OF CANDEIA
}

\author{
Antonio Donizette de Oliveira ${ }^{1}$, Ivonise Silva Andrade Ribeiro ${ }^{2}$, José Roberto Soares Scolforo², \\ José Márcio de Mello4 ${ }^{4}$ José Luiz Pereira de Rezende ${ }^{5}$
}

(received: February 5, 2009; accepted: April 30, 2010)

\begin{abstract}
Candeia wood (Eremanthus erythropappus) is widely used for production of essential oil and its active ingredient, alpha-bisabolol, is consumed by both the cosmetics and pharmaceutical industry. This study aimed to determine the productivity and operating costs associated with exploration, transportation and commercialization of candeia timber obtained from sustainable management systems and used for oil production; to determine the gross income or revenue obtained from the sale of candeia timber; to analyze the economic feasibility of sustainable management of candeia. For the economic analysis, Net Present Value, Net Present Value over an infinite planning horizon, and Average Cost of Production methods were used. Results indicated that the most significant costs associated with candeia forest management involve transportation and exploration. Together they account for $64 \%$ of the total management cost. Candeia forest management for oil production is economically feasible, even in situations where the interest rate is high or timber price drops to levels well below currently effective prices. As far as candeia forest management is concerned, shorter harvest cycles allow higher profitability. However, even in situations where the harvest cycle is relatively long ( 30 years), the activity is still economically feasible.
\end{abstract}

Key words: Eremanthus erythropappus, alpha-bisabolol, Net Present Value.

\section{ANÁLISE ECONÔMICA DO MANEJO SUSTENTÁVEL DA CANDEIA}

RESUMO: A madeira de candeia (Eremanthus erythropappus) é muito utilizada para a produção de óleo essencial, cujo princípio ativo, o alfa-bisabolol, é consumido pelas indústrias de cosméticos e medicamentos. Neste estudo, objetivou-se determinar os rendimentos e os custos das operações relacionadas à exploração, transporte e comercialização de madeira de candeia obtida em sistemas de manejo sustentável e utilizada para a produção de óleo; determinar a receita ou renda bruta obtida com a venda de madeira de candeia; analisar a viabilidade econômica do manejo sustentável dessa espécie. Para a análise econômica, utilizaram-se os métodos do Valor Presente Líquido, Valor Presente Líquido com horizonte de planejamento infinito e Custo Médio de Produção. Os resultados indicaram que os custos mais significativos relacionados ao manejo da candeia são o de transporte e o de exploração. Juntos eles representam $64 \%$ do custo total do manejo. O manejo da candeia visando a obter madeira para a produção de óleo é viável economicamente, mesmo em situações em que a taxa de juros é alta, ou o preço da madeira cai a níveis bem abaixo dos atualmente vigentes no mercado. Ciclos de corte mais curtos possibilitam a obtenção de lucratividades maiores no manejo da candeia. Contudo, mesmo em situações em que o ciclo de corte seja relativamente longo (30 anos), a atividade é economicamente viável.

Palavras-chave: Eremanthus erythropappus, alfa-bisabolol, Valor Presente Líquido.

\section{INTRODUCTION}

Sustainable forest management contributes to the maintenance and suitable use of forest coverings, while favoring the development of quantitative analysis techniques to help the decision-making process regarding the composition, structure and location of a forest in such way as to bring quantitative and qualitative environmental, economic and social benefits, maintaining diversity and ensuring forest sustainability. Sustainable management can additionally reconcile the harvest of forest products with conservation of local biodiversity, ensuring reliable supply of resources for generations to come (PINTO, 2000).

According to Amaral et al. (1998), chief reasons to implement a forest management plan include: a) production continuity, since a management plan ensures local timber production indefinitely while demanding half the time required for non-managed or conventional harvesting; $b$ )

${ }^{1}$ Forest Engineer, Professor, Dr. in Forest Science - Departamento de Ciências Florestais - Universidade Federal de Lavras - Cx. P. 3037 37200-000 - Lavras, MG - donizete@dcf.ufla.br

${ }^{2}$ Forest Engineer, D.S. - Departamento de Ciências Florestais - Universidade Federal de Lavras - Cx. P. 3037 - $37200-000$ - Lavras, MG - ivoniseribeiro@ hotmail.com

${ }^{3}$ Forest Engineer, Professor, Dr. in Forest Engineering - Departamento de Ciências Florestais - Universidade Federal de Lavras - Cx. P. 3037 - 37200-000 - Lavras, MG - jscolforo@dcf.ufla.br

${ }^{4}$ Forest Engineer, Professor, Dr. in Forest Resources - Departamento de Ciências Florestais - Universidade Federal de Lavras - Cx. P. 3037 - 37200-000 - Lavras, MG - josemarcio@dcf.ufla.br

${ }^{5}$ Forest Engineer, PhD in Forest Economy - Departamento de Ciências Florestais/DCF - Universidade Federal de Lavras/UFLA - Cx. P. 3037 - 37200-000 - Lavras, MG - jlprezen@dcf.ufla.br

Cerne, Lavras, v. 16, n. 3, p. 335-345, jul./set. 2010 
profitability, since economic benefits derived from suitable management outweigh costs by increasing labor productivity and reducing wood waste; c) workplace safety, since forest management techniques drastically reduce risks of occupational accidents; d) law obedience; e) market opportunities, since by adopting a sound management plan companies become likely candidates for the green label certification, and as more and more timber consumers are demanding this certification, particularly in Europe and in the U.S., holders of a green label can prove that their timber comes from a sustainable source, helping them sell their product in the international market; f) forest conservation, since a forest management plan ensures maintenance of the local forest covering, preserving most of the original plant diversity with a less severe impact on the local fauna if compared to non-managed harvesting; g) and environmental services, since sustainably managed forests help maintain local and global climates in equilibrium, especially through hydrologic cycle maintenance and carbon retention.

Following this line of reasoning, Scolforo (1998) argued that underlying principles of sustainable forest management include conservation of natural resources, conservation of the local forest structure and its functions, maintenance of biological diversity and local socioeconomic development. He also defines that in order to ensure feasibility of this technique it is necessary: a) to produce a detailed inventory of available resources so as to ensure information reliability; to characterize the forest site and structure; b) to identify, analyze and control environmental impacts according to effective legislation; c) to assess technical and economic feasibility as well as social consequences; d) to secure exploration procedures capable of minimizing damages to the ecosystem; e) to assess remnant stocks of the resource in order to guarantee sustained forest production; f) to adopt adequate silvicultural systems; g) and to use suitable cultivation techniques whenever required.

Candeia (Eremanthus erythropappus) is a native forest species whose timber is widely used for production of fence posts and essential oil, the active ingredient of which is alpha-bisabolol, consumed by both the cosmetics and pharmaceutical industry. According to Oliveira et al. (2009), alpha-bisabolol is used by the perfume, medicine and cosmetic industry to formulate lipsticks, suntan lotions, dental creams, after-shaves, shaving creams, hair removal products, to name a few.

Despite its high economic potential and pressing demands for its exploration, information is still scarce about determination and valuation of costs associated with sustainable management of candeia or about its economic feasibility.

This study aimed to determine productivity and operating costs associated with exploration, transportation and commercialization of candeia timber obtained from sustainable management systems and used for oil production; to determine the gross income or revenue obtained from sale of candeia timber; and to analyze the economic feasibility of sustainable management of candeia.

\section{MATERIAL AND METHODS}

\subsection{Study site}

The study site consists of native forest fragments predominantly formed (over $70 \%$ ) by candeia trees (Eremanthus erythropappus), explored for implementation of a forest management plan. The fragments are located within the bounds of 'Fazenda Bela Vista', a property in the municipality of Baependi, Minas Gerais state, at latitude $21^{\circ} 58^{\prime} 23^{\prime}$ ' south and longitude $44^{\circ} 44^{\prime} 35^{\prime}$ ' west. The local altitude ranges between 1,350 and $1,700 \mathrm{~m}$, and the climate according to Köppen classification is $\mathrm{Cwb}$, which means a temperate, humid, tropical highland climate, with mild summers. Temperatures in the hottest month are below $22^{\circ} \mathrm{C}$ while average annual temperatures range between $18^{\circ}$ and $19^{\circ} \mathrm{C}$, and average annual rainfall is around 1,400 $\mathrm{mm}$. December, January and February are the rainiest months, while June, July and August are the driest. The predominant local soil is Red-Yellow Latosol.

\subsection{Economic analysis of candeia management}

\subsubsection{Determination of productivity and operating costs}

Productivity and operating costs were determined in association with the exploration and transportation of candeia timber used for oil production, in sustainable management systems. Post-exploration costs comprising expenses with land clearing, plowing etc. were also determined, as they are necessary to leave the relevant area ready to receive seeds from remaining trees, which will function as seed trees.

To obtain data for determination of productivity and operating costs, spreadsheets were filled out by field teams who worked in partnership with workers engaged in operations to establish the management systems.

Management plan developers from two oilproducing companies were also interviewed to provide 
information on costs involving property map development, timber transportation and other related costs. This information was contrasted with data obtained by field teams in order to identify data inconsistencies or errors.

\subsubsection{Determination of revenues from management}

Revenues were obtained by multiplying the timber sale price for oil production by the timber output. Information on timber sale price was obtained from interviews with the owners of two oil-producing companies and with candeia landowners engaged in the management project.

The following conditions of sale were analyzed: standing timber (stumpage), timber felled and hauled to roadside by rural producer, and timber delivered to oil mill by rural producer.

\subsubsection{Economic feasibility of forest management}

To analyze the economic feasibility of sustainable candeia forest management, two situations were considered: a finite planning horizon consisting of a single harvest, and an infinite planning horizon consisting of indefinite harvests.

\subsubsection{Single harvest planning horizon}

Figure 1 illustrates the cash flow representing this situation. This model assumes that landowner tasks include timber removal, soil clearing and scarification (one year after harvest), and thinning of natural regeneration (two years after harvest). A 15-year harvest cycle was considered with no subsequent use of the area for timber production.

The economic analysis was performed using Net Present Value (NPV) and Average Production Cost (APC) methods, for an $8 \%$ interest rate per year.

NPV of an investment project can be defined as being the algebraic sum of values deducted from the relevant cash flow, and is given by (COELHO JUNIOR et al, 2008):

$N P V=\sum_{j=0}^{n} R_{j}(1+i)^{-j}-C_{j}(1+i)^{-j} \sum_{j=o}^{n}$

where $\mathrm{Cj}$ is the cost at the end of year $\mathrm{j}$ or period being considered, $\mathrm{Rj}$ is the revenue at the end of year $\mathrm{j}$ or period being considered, $i$ is the rate of interest or discount and $n$ is the project period, in years, or in number of periods.

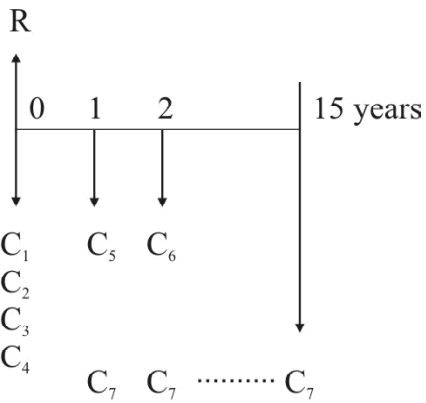

Where:

$\mathrm{R}$ - Revenue from sale of timber in each harvest cycle

$\mathrm{C} 1$ - Cost of management plan development

$\mathrm{C} 2$ - Cost of exploration (harvest)

C3 - Cost of transportation

C4 - Cost of fees and taxes

$\mathrm{C} 5$ - Cost of land clearing and scarification

C6 - Cost of thinning natural regeneration

C7 - Annual cost of land

Figure 1 - Cash flow for economic analysis of candeia forest management over a single harvest planning horizon.

Figura 1 - Fluxo de caixa para análise econômica do manejo da candeia em horizonte de planejamento de um corte.

The economic feasibility of a project as analyzed by the NPV method is indicated by the positive difference between revenues and costs, updated according to a given discount rate. The higher the NPV, the more attractive the project is. Conversely, a negative NPV signals economically unfeasibility.

APC results from the Total Discounted Cost (TDCj) and Total Equivalent Output (TEOj) relationship. It is necessary that these values be converted in the same period. APC can be calculated by the formula (REZENDE \& OLIVEIRA, 2008):

$$
\mathrm{APC}=\frac{\sum_{j=0}^{n} T D C_{j}}{\sum_{j=0}^{n} T E O_{j}}
$$

To determine whether the project is feasible one must compare the average cost of production of one unit to the market value of the product.

\subsubsection{Infinite harvest planning horizon}

This model assumes that candeia wood will be explored in each harvest cycle (rotation or interval between

Cerne, Lavras, v. 16, n. 3, p. 335-345, jul./set. 2010 
successive harvests) and that the volume of timber obtained in subsequent harvests will always be same as in the first harvest. Since no studies have been conducted to show ideal harvest cycles for fragments of native candeia subjected to sustainable management, several scenarios were established to simulate possible harvest cycles for the species. Simulations considered harvest cycles of 15 to 30 years. For instance, a 15-year cycle presupposes that over this span the candeia forest will produce the same volumetric yield as before exploration. Figure 2 illustrates the cash flow representing such situation.

The economic analysis was done using the Net Present Value method, over an infinite planning horizon $\left(\mathrm{NPV}_{\infty}\right)$ which, according to Oliveira et al (2008), is obtained as follows:

$N P V_{\infty}=\frac{N P V(1+i)^{n}}{(1+i)^{n}-1}$

where $\mathrm{n}$ is the duration of the harvest cycle, in years.

A given candeia forest management project or plan will be considered economically feasible if $\mathrm{NPV}_{\infty}$ is positive. The higher $\mathrm{NPV}_{\infty}$ is, the more attractive the plan is and, conversely, a negative value signals that the project is economically unfeasible.
A sensitivity analysis was performed to check the effect of interest rate, timber price, forest productivity and cost of exploration on the economic feasibility of management.

\section{RESULTS AND DISCUSSION}

\subsection{Forest management costs}

\subsubsection{Costs involving management plan development}

\subsubsection{Preparing a property map}

Using a GPS, a topographic survey is done to map property boundaries within which sustainable management of candeia will take place. It is necessary to identify the borders of the land, demarcate streamlets and headwaters, permanent preservation areas (APPs) and legal reserve areas to be recorded for the property in question. Based on this information, a property map is drawn using appropriate software (Arcmap or Autocad).

The cost involving preparation of a property map with all the necessary information for approval of the management plan is around $\mathrm{R} \$ 12.00$ per hectare.

\subsubsection{Forest inventory and development of the management plan}

Two situations should be considered to produce an inventory of candeia forest fragments: small fragments

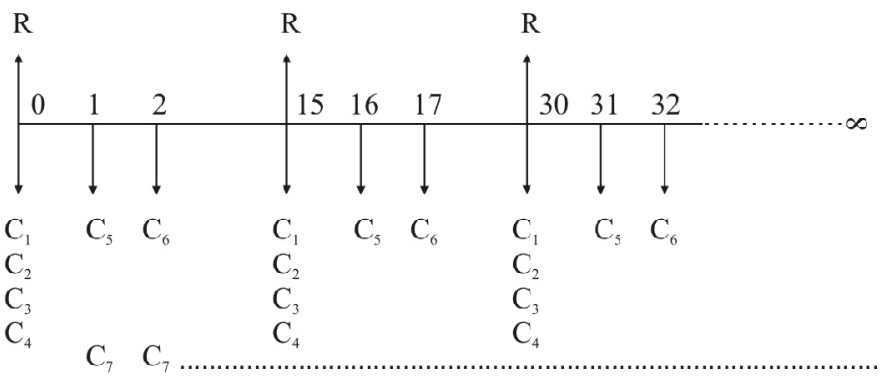

Where:

$\mathrm{R}$ - Revenue from sale of timber in each harvest cycle

$\mathrm{C} 1$ - Cost of management plan development

$\mathrm{C} 2$ - Cost of exploration

C3 - Cost of transportation

$\mathrm{C} 4$ - Cost of fees and taxes

C5 - Cost of land clearing and scarification

C6 - Cost of thinning natural regeneration

C7 - Annual cost of land

Figure 2 - Cash flow for economic analysis of candeia forest management over an infinite harvest planning horizon.

Figura 2 - Fluxo de caixa para análise econômica do manejo da candeia em horizonte de planejamento de infinitos cortes.

Cerne, Lavras, v. 16, n. 3, p. 335-345, jul./set. 2010 
(up to 10 ha in area) require inventorying all trees $5 \mathrm{~cm}$ or more in diameter, and large fragments (more than 10 ha in area) require a suitable sampling procedure assigning $1,000 \mathrm{~m}^{2}$ plots and inventorying trees $5 \mathrm{~cm}$ or more in diameter.

In order to proceed with the inventory according to diameter class, the most common procedure is to use a diameter fork. With this information and using the procedure defined in regulation 001/2007 of the Minas Gerais State Forest Institute (IEF), the volume of timber per hectare and per the entire fragment is derived.

It should be noted that in order to implement a sustainable management plan in a fragment it is necessary that more than $70 \%$ of its area be composed of candeia, according to provisions in regulation $001 / 2007$ of the above IEF.

While taking measurements for the inventory, any bromeliads or orchids anchored on trees should be noted so that prior to tree cutting they are transplanted into other areas.

The tree inventory is usually performed by a team of 5 people, one taking notes and the others measuring tree diameters. The cost of gathering and processing inventory data and developing the management plan is $\mathrm{R} \$ 16.40$ per stere meter of timber.

According to information from interviews with developers of management plans in two candeia oil mills, on average a candeia fragment yields $45 \mathrm{~m}^{3} / \mathrm{ha}$ and the average stack factor (solid volume to stacked volume conversion factor) for this species is 2.67. Based on this information, the inventory cost is $\mathrm{R} \$ 1,970.46 / \mathrm{ha}$.

\subsubsection{Costs of exploration}

Costs itemized here refer to exploration of candeia fragments to be managed according to the seed tree system.

\subsubsection{Identifying and marking seed trees}

The seed tree system consists of leaving a sufficient quantity of seed-producing trees distributed across the entire area, so as to secure an adequate population size in new stands. Usually, seed trees are left six to eight meters apart.

Data obtained in this study show that, in order to identify and mark seed trees, a trained person spends an average of 3 hours to cover one hectare.

To determine the cost of the above activity per hectare, the criterion applied considers expenses with one worker receiving a minimum wage $(\mathrm{R} \$ 415.00)$ accrued of payroll charges estimated at $70 \%$ of the minimum wage (R\$ 290.50), with 176 worked hours per month, according to labor legislation. Thus, the cost of one hour of labor is $\mathrm{R} \$ 4.00$ and the average cost of this activity is $\mathrm{R} \$ 12.00$ per hectare.

\subsubsection{Transplantation of epiphytes anchored on trees}

It is necessary to remove any epiphytes anchored on inventoried trees and transplant them into neighboring area, preferably permanent preservation areas, legal reserve areas etc. The productivity of this operation will depend on the intensity of epiphyte occurrence and on the distance between original site and transplantation site. Assuming an average intensity of epiphyte occurrence (around 100 epiphytes/hectare) and a distance of up to one kilometer, a person spends around 2.5 hours per hectare to perform the transplantation job. Thus, considering the cost of one hour of labor at $\mathrm{R} \$ 4.00$, the cost of this activity is $\mathrm{R} \$ 10.00 / \mathrm{ha}$.

\subsubsection{Tree felling and bucking}

Trees are felled and cut into logs about 1 meter in length, and any branches at least $3 \mathrm{~cm}$ in diameter are also used. Usually, trees are felled using a chainsaw and the productivity of this operation will vary depending on tree diameter and height, on tree density per unit of area, on local topography and other drawbacks encountered by the chainsaw operator throughout.

On average, a worker manages 7 stere meters of timber in one day's work. Assuming a day's work of 8 hours, 0.88 stere meter is yielded per hour.

Usually, payment for labor required to perform this activity is based on stere meter yield of cut timber. The average cost is R $\$ 12.00$ /stere meter, inclusive of expenses with chainsaw, food, transportation, fuel, assisting person etc. Assuming that on average a candeia fragment produces $45 \mathrm{~m}^{3} /$ ha, the cost of tree felling and bucking is around $\mathrm{R} \$$ $1,441.80 /$ ha, for a stack factor of 2.67 .

\subsubsection{Exploitation (Log hauling)}

Log hauling is usually performed by one worker using 2 to 3 donkeys for hauling logs to the closest local roadside. Each animal hauls around 0.25 stere meter of timber per trip covering an average distance of 500 meters. In an 8-hour day's work each animal makes 8 trips. Assuming that 2 donkeys are used, one worker manages to haul 4 stere meters of timber a day. These values may vary depending on log diameter, proximity of destination roadside, local topography, and other drawbacks encountered by the worker to remove the load. The price paid per stere meter of hauled timber is $\mathrm{R} \$$ 13.00. Assuming that on average a candeia fragment produces $45 \mathrm{~m}^{3} / \mathrm{ha}$, the cost of $\log$ hauling is around $\mathrm{R} \$$ $1,561.95 /$ ha, for a stack factor of 2.67 .

Cerne, Lavras, v. 16, n. 3, p. 335-345, jul./set. 2010 


\subsubsection{Cost of transportation}

Usually, two types of vehicles are used for transportation of timber to the oil mill. Where the distance from point of origin to mill is small, a truck with a capacity of 16 to 17 stere meters of timber is used. For longer distances, a truck with a capacity of around 40 stere meters is used instead.

Considering an average distance of $630 \mathrm{~km}$, the cost of transportation with a truck is around $\mathrm{R} \$ 1,500.00$ per trip, resulting in $\mathrm{R} \$ 37.50 /$ stere meter. As on average a candeia fragment produces $45 \mathrm{~m}^{3} / \mathrm{ha}$, the cost involving timber transportation to the mill yard is around $\mathrm{R} \$ 4,505.62 / \mathrm{ha}$, for a stack factor of 2.67.

\subsubsection{Cost of land clearance and scarification after harvest}

To perform this activity a hoe or mattock is used. Its purpose is to break up the surface and turn over the top soil layer which is usually very compacted, so as to leave the harvested area ready to receive seeds from seed trees. This operation should be conducted close to the seed dispersion season (August to September).

Land clearing and scarification is done in circles around $60 \mathrm{~cm}$ in diameter, equally distant by 2 meters. The soil is turned over up to $5 \mathrm{~cm}$ in depth.

The required labor productivity to develop this activity will depend on various factors, including soil type, local topography, undergrowth type etc.

Taking into account these possible drawbacks, a worker manages to clear and scarify an average area of 650 $\mathrm{m}^{2}$ per day's work ( 8 hours). Thus, at a cost of $\mathrm{R} \$ 4.00$ per worked hour, $\mathrm{R} \$ 492.31 / \mathrm{ha}$ is spent to do this activity.

\subsubsection{Cost of fees and taxes}

This item covers expenses with forest exploration license (APEF) and payment of state value-added tax (ICMS).

Prior to tree harvest, it is necessary to apply for a forest exploration license (APEF) at the State Forest Institute (IEF). The fee charged is $\mathrm{R} \$ 0.50 / \mathrm{m}^{3}$ of timber harvested. Assuming that on average a candeia fragment produces 45 $\mathrm{m}^{3} / \mathrm{ha}$, the cost of an APEF license is around $\mathrm{R} \$ 22.50 / \mathrm{ha}$.

In order for timber to be transported, the buying mill needs to produce an Environmental Control Guide (GCA) while the landowner or forest lessee needs to issue an invoice to the mill which will include IEF stamps. Upon receipt, the landowner pays $12 \%$ of state value-added tax (ICMS) on the aggregate value of timber to be transported. Thus, considering a sale price of timber delivered to the roadside at $\mathrm{R} \$ 115.00 /$ stere meter and assuming that on average a candeia fragment produces $45 \mathrm{~m}^{3} / \mathrm{ha}$, the cost of ICMS is around $\mathrm{R} \$ 1,658.07 / \mathrm{ha}$, for a stack factor of 2.67 .

\subsubsection{Cost of thinning natural regeneration}

Following seed dispersion, a span of around 2 years is required for natural regeneration to be restored in areas covered by the management plan. After this period, plants should be one meter high on average, taking into account established plants (height $>1.50 \mathrm{~m}$ ), unestablished plants (height $<0.30 \mathrm{~m}$ ) and regenerating plants (height between 0.30 and $1.50 \mathrm{~m}$ ), and there should be a large quantity of plants in the circles subjected to clearing and scarification. Thinning is done to reduce plant density per unit of area and, consequently, reduce competition between remaining plants and thus hasten their development.

Plant thinning can be done by one worker using a scythe, being sure to leave a distance of around 2.0 meters between the remaining plants which, whenever possible, should be the tallest and better shaped.

On average, a worker spends 20 hours to thin 1 hectare. Thus, assuming that one hour of labor costs R\$ 4.00 , the cost of this activity is $R \$ 80.00 /$ ha.

\subsubsection{Cost of land}

Annual cost of land is considered to be the interest rate on the value of this production factor. In the study area, land price ranges from $\mathrm{R} \$ 1,000.00$ to $\mathrm{R} \$ 3,000.00$ per hectare. For purposes of economic analysis, an average value of $R \$$ $2,000.00$ was computed. Thus, assuming an interest rate of $8 \%$ p.a. the annual cost of land is $\mathrm{R} \$ 160.00 / \mathrm{ha}$.

\subsubsection{Summary of forest management costs}

Table 1 provides a summary of average costs for candeia forest management. The sum of all costs is $\mathrm{R} \$$ $99.27 /$ stere meter, or $\mathrm{R} \$ 265.04 / \mathrm{m}^{3}$, or $\mathrm{R} \$ 11,926.71 / \mathrm{ha}$. Transportation cost contributes the largest percentage in the total cost (37.78\%), followed by exploration (25.37\%), management plan preparation $(16.62 \%)$, fees and taxes (14.09\%), land clearing and scarification (4.13\%) and thinning of natural regeneration $(0.67 \%)$ costs.

The cost of hauling timber to the roadside ready for transportation, a result of the sum of management plan preparation, exploration, and fees and taxes costs, is $\mathrm{R} \$$ 55.67 per stere meter. Besides these costs, the landowner has to bear the costs of clearing and scarifying the land (year 1) and thinning (year 2). Even then, it is clearly noticeable that selling timber at $\mathrm{R} \$ 115.00 /$ stere meter is highly lucrative. 
Table 1 - Average costs involving candeia forest management.

Tabela 1 - Custos médios do manejo da candeia.

\begin{tabular}{|c|c|c|c|c|}
\hline \multirow[b]{2}{*}{ Cost itemization } & \multicolumn{3}{|c|}{ Costs $(\mathrm{R} \$)^{*}$} & \multirow{2}{*}{$\begin{array}{l}\text { Contribution } \\
(\%)\end{array}$} \\
\hline & $\begin{array}{c}\text { Per stere } \\
\text { meter }\end{array}$ & Per $\mathrm{m}^{3}$ & Per ha & \\
\hline \multicolumn{5}{|l|}{1 - Management plan development (year 0) } \\
\hline - Property map & 0.10 & 0.27 & 12.00 & 0.10 \\
\hline - Forest inventory and management plan & 16.40 & 43.79 & $1,970.46$ & 16.52 \\
\hline Subtotal 1 & 16.50 & 44.06 & $1,982.46$ & 16.62 \\
\hline \multicolumn{5}{|l|}{2 - Exploration (year 0) } \\
\hline - Identifying and marking seed trees & 0.10 & 0.27 & 12.00 & 0.10 \\
\hline - Epiphyte transplantation & 0.08 & 0.22 & 10.00 & 0.08 \\
\hline - Tree felling and bucking & 12.00 & 32.04 & $1,441.80$ & 12.09 \\
\hline - Log hauling & 13.00 & 34.71 & $1,561.95$ & 13.10 \\
\hline Subtotal 2 & 25.18 & 67.24 & $3,025.75$ & 25.37 \\
\hline 3 - Log transportation (year 0) & 37.50 & 100.12 & $4,505.62$ & 37.78 \\
\hline 4 - Land clearing and scarification after harvest (year 1) & 4.10 & 10.94 & 492.31 & 4.13 \\
\hline \multicolumn{5}{|l|}{5 - Fees and taxes (year 0 ) } \\
\hline - APEF & 0.19 & 0.50 & 22.50 & 0.19 \\
\hline - ICMS & 13.80 & 36.85 & $1,658.07$ & 13.90 \\
\hline Subtotal & 13.99 & 37.35 & $1,680.57$ & 14.09 \\
\hline 6 - Thinning of natural regeneration (year 2) & 0.67 & 1.78 & 80.00 & 0.67 \\
\hline 7 - Annual cost of land & 1.33 & 3.55 & 160.00 & 1.34 \\
\hline Grand Total & 99.27 & 265.04 & $11,926.71$ & 100.00 \\
\hline
\end{tabular}

\subsection{Revenues from forest management}

Revenues were derived by multiplying timber sale price by product output. The following conditions of sale were considered: standing timber ( $\mathrm{R} \$ 50.00 /$ stere meter), timber felled and hauled to roadside by rural producer ( $\mathrm{R} \$$ $115.00 /$ stere meter) and timber delivered to oil mill by rural producer ( $\mathrm{R} \$ 175.00 /$ stere meter). Table 2 provides revenues from timber sale in candeia forest management.

\subsection{Economic feasibility of forest management}

\subsubsection{Single harvest planning horizon}

Table 3 provides the economic analysis over a single harvest planning horizon. NPV values show that the profit obtained with candeia management is greater when timber is delivered to the mill yard at $\mathrm{R} \$ 175.00 /$ stere meter. It should be noted that results are valid only for the conditions of cost, timber price and forest productivity considered in Table 2 . For instance, if transportation cost exceeds $\mathrm{R} \$ 37.50 /$ stere meter, the NPV drops and, depending on the magnitude of this cost, selling timber hauled to the roadside at $R \$ 115.00$ / stere meter can be more interesting. Naturally, in order for timber sale delivered to the mill yard to be feasible, the cost of transportation may not exceed $\mathrm{R} \$ 60.00$, which is the difference between timber sale price delivered to the roadside and the price delivered to the mill yard.

The low APC value for standing timber ( $\mathrm{R} \$ 15.76$ / stere meter) is due to the way the economic analysis was conducted. It was assumed that the landowner will only bear land clearing and scarification costs and thinning of natural regeneration costs, while other costs are born by the buyer.

A R $\$ 71.43$ production cost per stere meter of timber delivered to the roadside indicates that, by selling timber at $\mathrm{R} \$ 115.00 /$ stere meter the landowner profits $\mathrm{R} \$ 43.57$ per stere meter of explored timber. Assuming a productivity of $45 \mathrm{~m}^{3} / \mathrm{ha}$ or 120.15 stere meters/ha, the profit per hectare is $\mathrm{R} \$ 5,234.52$ (NPV).

Cerne, Lavras, v. 16, n. 3, p. 335-345, jul./set. 2010 
Table 2 - Revenues from timber sale in candeia forest management.

Tabela 2 - Receitas obtidas com a venda de madeira de candeia oriunda do manejo.

\begin{tabular}{lccc}
\hline Revenue itemization & $\begin{array}{c}\text { Price } \\
(\mathrm{R} \$ / \mathrm{stm} *)\end{array}$ & $\begin{array}{c}\text { Volume } \\
(\mathrm{stm} * / \mathrm{ha})\end{array}$ & $\begin{array}{c}\text { Revenue } \\
(\mathrm{R} \$ / \mathrm{ha}) *\end{array}$ \\
\hline Standing timber & 50.00 & 120.15 & $6,007.50$ \\
Timber felled and hauled to roadside by producer & 115.00 & 120.15 & $13,817.25$ \\
Timber felled and delivered to mill yard by producer & 175.00 & 120.15 & $21,026.25$ \\
\hline
\end{tabular}

* Parameters used: stack factor $=2.67$; Average volume of candeia timber obtained per hectare: $45 \mathrm{~m}^{3} / \mathrm{ha}$ (Regulation IEF 01/2007).

$*$ stm $=$ stere meter.

Table 3 - Net Present Value (NPV) and Average Production Cost (APC) for a single harvest planning horizon, and an $8 \%$ annual interest rate.

Tabela 3 - Valor Presente Líquido (VPL) e Custo Médio de Produção (CMPr) para o manejo da candeia em horizonte de um corte, e taxa anual de juros de $8 \%$.

\begin{tabular}{lcc}
\hline Timber sale & NPV & APC \\
& $(\mathrm{R} \$ / \mathrm{ha})$ & $(\mathrm{R} \$ /$ stere meter $)$ \\
\hline Standing timber & $4,113.55$ & 15.76 \\
Delivered to roadside & $5,234.52$ & 71.43 \\
Delivered to mill yard & $7,937.90$ & 108.93 \\
\hline
\end{tabular}

\subsubsection{Infinite harvest planning horizon}

\subsubsection{Simulation of candeia harvest cycles}

Table 4 provides $\mathrm{NPV}_{\infty}$ values for various candeia harvest cycles. For the same condition of sale, $\mathrm{NPV}_{\infty}$ drops as harvest cycle increases, in other words, shorter harvest cycles enable higher profit per hectare in candeia forest management. This is expected because the volume of timber in each harvest is assumed to be the same $\left(45 \mathrm{~m}^{3} / \mathrm{ha}\right)$, irrespective of the cycle span, in years. For instance, harvesting every 15 years is more profitable than doing it every 16 years, since in both situations the expected volume does not change.

One thing to consider is, whether after each 15year cycle the volume of timber will indeed be the same or very close to the original volume of the forest, in other words, whether the harvest cycle span will only be 15 years. However, this will only be defined after studies on regeneration and management of candeia are completed, in a few years time. It becomes clear from economic analysis results that, even for a 30-year harvest cycle, candeia forest management seems perfectly feasible economically.

The most interesting option is to sell timber delivered to the mill yard. However, this is only true if the landowner sells it at $\mathrm{R} \$ 175.00 /$ stere meter and does transportation for $\mathrm{R} \$ 37.50 /$ stere meter, values used in the economic analysis. The most common procedure is to sell timber delivered to the roadside, in other words, the buyer bears the transportation cost. So, from this point on, the economic analysis will be based on this situation.

\subsubsection{Sensitivity analysis}

The sensitivity analysis or scenario simulation allows analyzing $\mathrm{NPV}_{\infty}$ behavior depending on changes in parameters. The effect of interest rate on the economic feasibility of candeia forest management is presented in Figure 3. As expected, high interest rates reduce profitability in candeia forest management. For instance, in a 15-year harvest cycle, the $\mathrm{NPV}_{\infty}$ drops from $\mathrm{R} \$ 12,797.85$ at a $4 \%$ rate to $R \$ 6,106.08$ at a $12 \%$ rate.

Figure 4 shows that even with timber price dropping, candeia forest management is still economically feasible for any harvest cycle being considered. For instance, in a 30year harvest cycle, if the stere meter price drops from $\mathrm{R} \$ 115.00$ to $\mathrm{R} \$ 85.00$, the $\mathrm{NPV}_{\infty}$ goes from $\mathrm{R} \$ 5,332.75$ to $\mathrm{R} \$ 1,810.79$.

A similar behavior is observed regarding changes in timber productivity (Figure 5). Even in fragments with low productivity $\left(35 \mathrm{~m}^{3} / \mathrm{ha}\right.$ ) profitability is good. It should be pointed out that the most significant costs in candeia forest management, including transportation and exploration, are variable costs in that they are attached to the volume of output. When the volume of output drops, these costs also drop, helping maintain the economic feasibility of the activity.

As mentioned before, the cost of exploration accounts for around $25 \%$ of the total cost in candeia forest management. Therefore, slight variations in this cost are significantly reflected in economic feasibility, as is illustrated in Figure 6. For instance, in a 20-year harvest cycle, a $10 \%$ reduction in this cost causes the $\mathrm{NPV}_{\infty}$ to rise from $R \$ 6,407.95$ to $R \$ 6,793.18$. 
Table $4-\mathrm{NPV}_{\infty}$ behavior for several candeia harvest cycles, considering various timber sale conditions, and an $8 \%$ annual interest rate. Tabela 4 - Comportamento do VPL $L_{\infty}$ para diversos ciclos de corte para a candeia, considerando várias situações de venda da madeira e taxa anual de juros de $8 \%$.

\begin{tabular}{cccc}
\hline \multirow{2}{*}{ Harvest cycle (years) } & \multicolumn{3}{c}{$\mathrm{NPV}_{\infty}(\mathrm{R} \$ \mathbf{h a})$} \\
\cline { 2 - 4 } 15 & Standing timber & Timber delivered to roadside & Timber delivered to mill yard \\
\hline 16 & $6,007.31$ & $7,644.34$ & $11,592.27$ \\
17 & $5,743.25$ & $7,326.30$ & $11,144.04$ \\
18 & $5,513.82$ & $7,049.96$ & $10,754.59$ \\
19 & $5,313.19$ & $6,808.31$ & $10,414.49$ \\
20 & $5,136.74$ & $6,595.79$ & $10,114.49$ \\
25 & $4,980.79$ & $6,407.95$ & $9,849.77$ \\
30 & $4,420.59$ & $5,733.23$ & $8,898.85$ \\
\hline
\end{tabular}

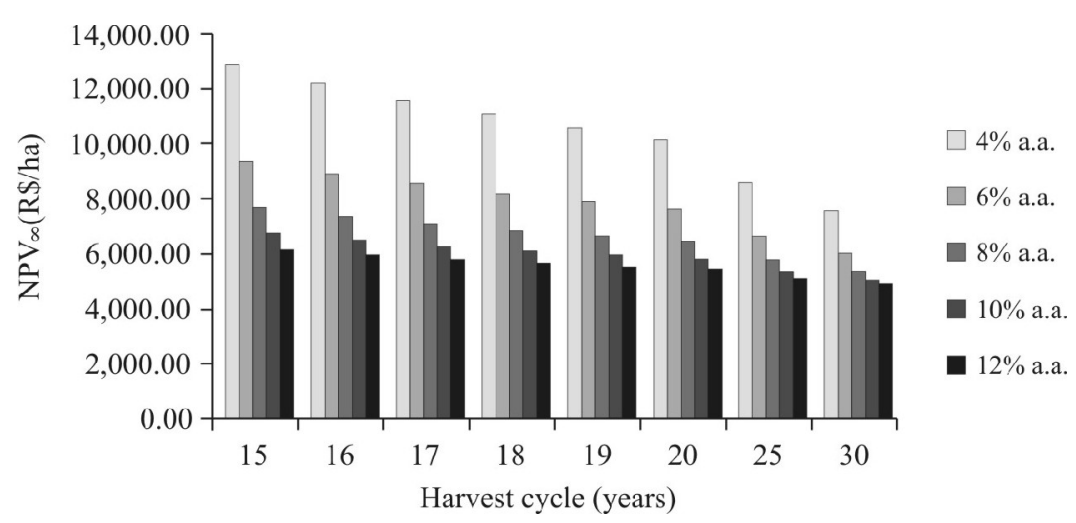

Figure $3-\mathrm{NPV}_{\infty}$ behavior depending on interest rate changes.

Figura 3 - Comportamento do $V P L_{\infty}$ em relação a alterações na taxa de juros.

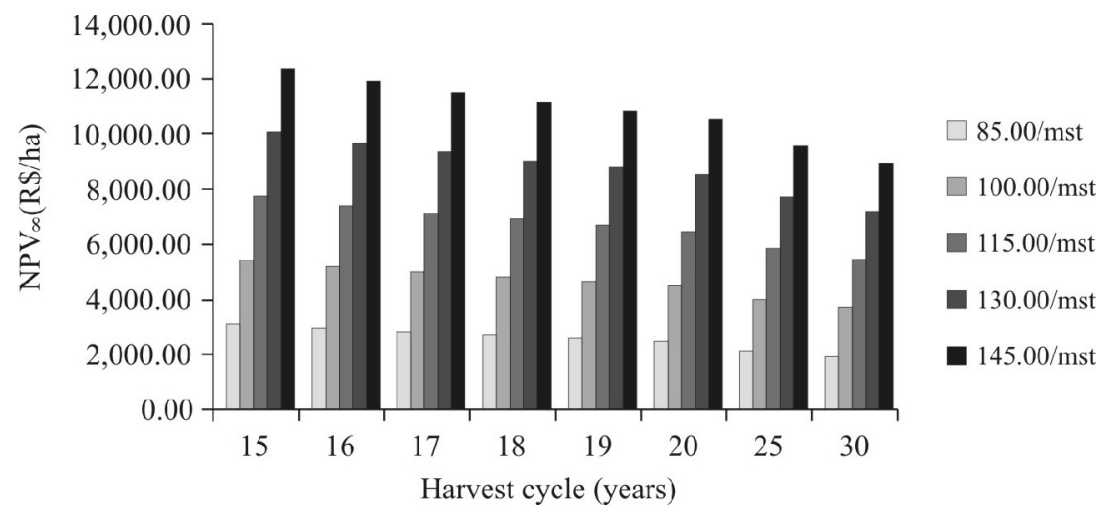

Figure $4-\mathrm{NPV}_{\infty}$ behavior depending on changes in sale price of timber delivered to roadside, at an $8 \%$ interest rate a year.

Figura 4 - Comportamento do VPL em relação a alterações no preço de venda da madeira colocada na beira da estrada, para taxa de juros de $8 \%$ ao ano. 


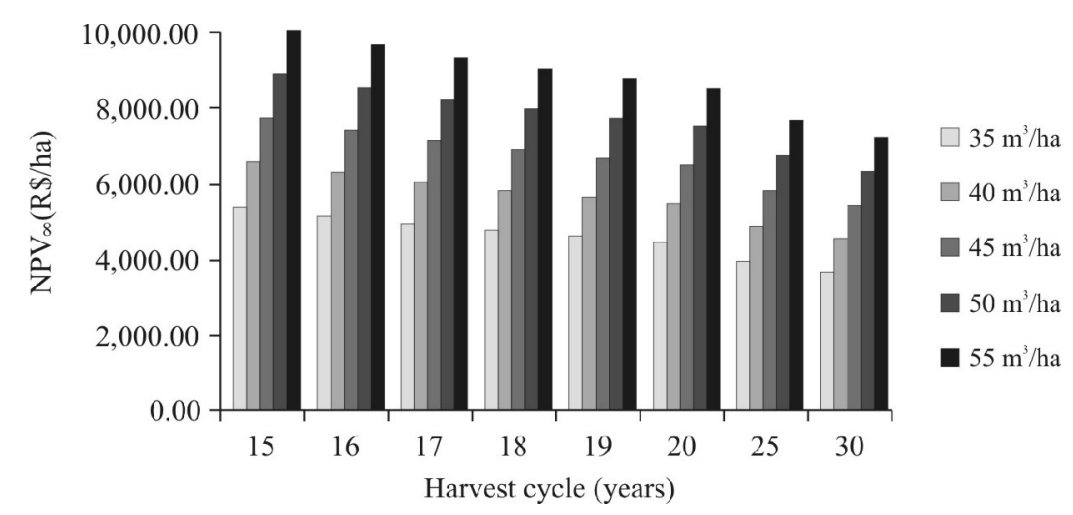

Figure $5-\mathrm{NPV}_{\infty}$ behavior depending on changes in timber productivity in a fragment, at an $8 \%$ interest rate a year.

Figura 5 - Comportamento do $V P L_{\infty}$ em relação a alterações na produtividade de madeira do fragmento a ser manejado, para taxa de juros de $8 \%$ ao ano.

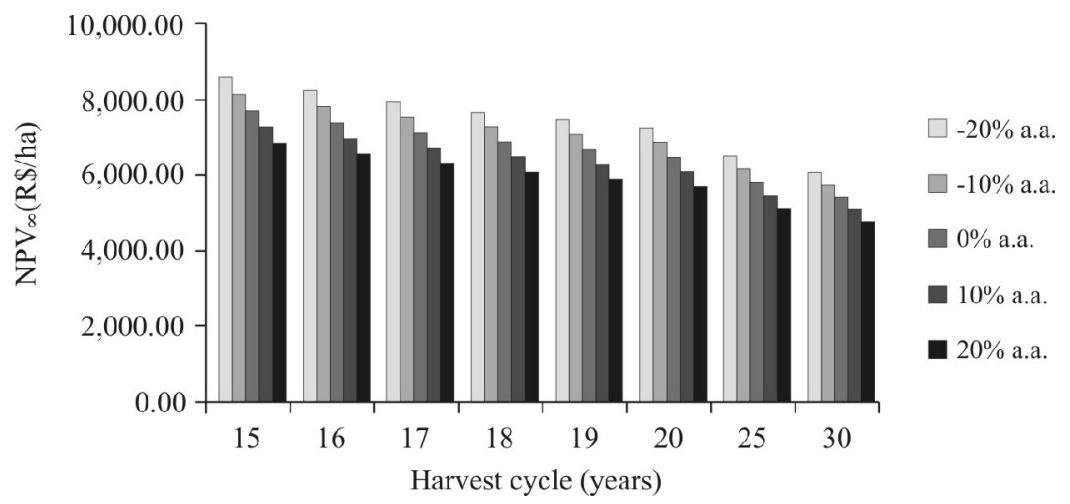

Figure 6 - $\mathrm{NPV}_{\infty}$ behavior depending on changes in exploration cost, at an $8 \%$ interest rate a year.

Figura 6 - Comportamento do $V P L_{\infty}$ em relação a alterações no custo de exploração, para a taxa de juros de $8 \%$ ao ano.

\section{CONCLUSIONS}

The most significant costs in candeia forest management are associated with transportation and exploration. Together they account for $63 \%$ of the total cost involved.

Candeia forest management intended for oil production is economically feasible, even in situations where the interest rate is high or timber price drops to levels well below currently effective market prices.

As far as candeia forest management is concerned, shorter harvest cycles allow greater profitability. However, even in situations where the harvest cycle is relatively long (30 years), the activity is still economically feasible.

\section{ACKNOWLEDGEMENTS}

We wish to thank the National Council for Scientific and Technological Development (CNPq) for granting the scholarship for research accomplishments to the first author, and also the Research Aid Foundation of Minas Gerais State (Fapemig) for granting the doctoral scholarship to the second author.

\section{BIBLIOGRAPHICAL REFERENCES}

ALENCAR, E. Abordagem interpretativa nas ciências sociais. Lavras: UFLA, 1996. 28 p. Mimeografado.

AMARAL, P.; VERÍSSIMO, A.; BARRETO, P.; VIDAL, E. Floresta para sempre: um manual para a produção de madeira na Amazônia. Belém: IMAZON, 1998. 137 p.

BENTLEY, W.; TEENGUARDEN, D. Financial maturity: a theory review. Forest Science, Washington, v. 11, n. 3, p. 7687, Mar. 1965. 
BLANCHARD, J.; PRADO, G. Natural regeneratio of Rizophora mangle in strip clearcuts in Northwest Ecuador. Biotropica, Washington, v. 27, n. 2, p. 160-167, June 1995.

CARVALHO, J. O. P. Inventário diagnóstico da regeneração natural da vegetação em áreas da Floresta Nacional do Tapajós no estado do Pará. 1982. 128 f. Dissertação (Mestrado em Ciência Florestal) - Universidade Federal do Paraná, Curitiba, 1982.

CARVALHO, P. E. R. Espécies florestais brasileiras: recomendações silviculturais, potencialidades e uso da madeira. Brasília: Embrapa-CNPF, 1994. 640 p.

CERVO, A. L.; BERVIAN, P. A. Metodologia científica. São Paulo: MacGraw-Hill, 1983. 249 p.

COELHO JUNIOR, L. M.; REZENDE, J. L. P.; OLIVEIRA, A. D.; COIMBRA, L. A. B.; SOUZA, A. N. Análise de investimento de um sistema agroflorestal sob situação de risco. Cerne, Lavras, v. 14 , n. 4 , p. $368-378$, out./dez. 2008.

CORRÊA, M. P. Dicionário de plantas úteis do Brasil. Rio de Janeiro: Ministério da Agricultura, 1931. v. 1, 433 p.

FERREIRA, A. B. de H. (Coord.). Minidicionário da língua portuguesa. 3. ed. Rio de Janeiro: Nova Fronteira, 1993. 577 p.

GUANZIROLI, C. E. Principais indicadores sócio-econômicos dos assentamentos de reforma agrária. In: ROMEIRO, A.; GUANZIROLI, C.; PALMEIRA, M.; LEITE, S. Reforma agrária: produção, emprego e renda: o relatório da FAO em debate. Rio de Janeiro: VOZES/IBASE/FAO, 1994. p. 13-68.

GUEDES, J. Z. G. G. Comercialização da carne bovina no Paraguai: uma abordagem da margem. 1999. 70 p. Dissertação (Mestrado em Administração Rural) - Universidade Federal de Lavras, Lavras, 1999.

MACLEISH, N. F. F. Revision of Eremanthus (Compositae: Vernonieae). Annals of the Missouri Botanical Garden, Saint Louis, v. 47, p. 265-290, 1987.
MARQUES, P.; AGUIAR, D. Comercialização de produtos agrícolas. São Paulo: EDUSP, 1993. 295 p.

MATTAR, F. N. Pesquisa de marketing: metodologia, planejamento, execução e análise. São Paulo: Atlas, 1993. $225 \mathrm{p}$.

OLIVEIRA, A. D.; FERREIRA, T. C.; SCOLFORO, J. R. S.; MELLO, J. M.; REZENDE, J. L. P. Avaliação econômica de plantios de Eucalyptus grandis para a produção de celulose. Cerne, Lavras, v. 14, n. 1, p. 82-91, jan./mar. 2008.

OLIVEIRA, A. D.; RIBEIRO, I. S. A.; SCOLFORO, J. R. S.; MELLO, J. M.; ACERBI JUNIOR, F. W.; CAMOLESI, J. F. Market chain analysis of candeia timber (Eremanthus erythropappus). Cerne, Lavras, v. 15, n. 3, p. 257-264, jul./set. 2009.

PÉREZ, J. F. M. Sistema de manejo para candeia (Eremanthus erythropappus (DC.) MacLeish). 2001. 71 p. Dissertação (Mestrado em Engenharia Florestal) - Universidade Federal de Lavras, Lavras, 2001.

PÉREZ, J. F. M.; SCOLFORO, J. R. S.; MELLO, J. M.; ACERBI JÚNIOR, F. W.; CAMOLESI, J. F. Equações para a estimativa do volume, peso seco, peso de óleo e número de moirões para a candeia (Eremantus erythropappus (DC.) MacLeisch). Cerne, Lavras, v. 10, n. 2, p. 257-273, 2004.

PINTO, A. C. M. Análise de danos de colheita de madeira em floresta tropical úmida sob regime de manejo florestal sustentável na Amazônia Ocidental. 2000. 165 p. Dissertação (Mestrado em Ciência Florestal) - Universidade Federal de Viçosa, Viçosa, 2000.

REZENDE, J. L. P.; OLIVEIRA, A. D. Análise econômica e social de projetos florestais. Viçosa, MG: UFV, 2008. $386 \mathrm{p}$.

SCOLFORO, J. R. S. Manejo florestal. Lavras: UFLA/FAEPE, 1998. 438 p.

Cerne, Lavras, v. 16, n. 3, p. 335-345, jul./set. 2010 